\title{
Reputation as an Intangible Asset
}

PhD candidate Nikolay Peshev

University of Economics - Varna, Varna, Bulgaria

nikolay_peshev@ue-varna.bg

\begin{abstract}
The topic of corporate reputation is facing growing attention among scholars and practitioners, during the last 20 years. Emerged as a blurry new paradigm with roots from the fields of economics, strategy, marketing, organization science, sociology, nowadays reputation is taking shape as an independent multidisciplinary construct, with considerable impact on corporate strategy and behavior. This article aims to review the nature of reputation as an economic asset that gains competitive advantage for the organization. Reputation creates value and the organizations are competing on reputational market, in addition to the classical challenges as capital, products, labor market.
\end{abstract}

Keywords: reputation, asset, stakeholders

JEL Code: L140 DOI: https://doi.org/10.36997/IJUSV-ESS/2020.9.1.80

\section{Definitional landscape of reputation}

The reputation of organizations as a relatively new phenomenon is the subject of growing interest from academia and companies. The growing interest in the topic has its digital expressions. Between 1969 and 2001, less than 10 publications containing the keyword 'reputation' were published annually in the academic Scopus Database. Their number reached 500 per year between 2002 and 2009. Reputation publications reached over 600 per year in the period $2010-2015$, when the total of 5885 were published. (Feldman et all, 2014)

The Oxford business dictionary defines reputation as "Beliefs or opinions that are generally held about someone or something", "a widespread belief that someone or something has a particular characteristic". (Webster et all, 1976) annotates the reputation as "the estimation in which one is generally held.

Currently, there is no agreement on one definition in regards to reputation. However, all of them are contributing to a better understanding of reputation. As a multi-disciplinary construct, reputation could be defined according to the point of view that helps a holistic understanding of reputation to be achived. A selected number of definitions of corporate reputation is presented by (Helm, 2011) in Table 1.

Table 1. Selected number of definitions of corporate reputation

\begin{tabular}{|l|l|}
\hline \multicolumn{1}{|c|}{ Author/s } & \multicolumn{1}{c|}{ Definitions } \\
\hline Balmer and Greyser (2003) & $\begin{array}{l}\text { "Reputation is "formed over time; based on what the organization } \\
\text { has done and how it has behaved" }\end{array}$ \\
\hline Bromley (2002) & $\begin{array}{l}\text { "Corporate reputation thus reflects a firm's relative standing, } \\
\text { internally with employees and externally with other stakeholders, } \\
\text { in its competitive and institutional environment" }\end{array}$ \\
\hline Fombrun (1996) & $\begin{array}{l}\text { "We define corporate reputation as the overall estimation in which } \\
\text { a company is held by its constituents" }\end{array}$ \\
\hline Fombrun (1996) & $\begin{array}{l}\text { "A corporate reputation is a perceptual representation of a } \\
\text { company's past actions and future prospects that describes the } \\
\text { firm's overall appeal to all of its key constituents when compared } \\
\text { with other leading rivals" }\end{array}$ \\
\hline Gotsi and Wilson (2001) & "A corporate reputation is a stakeholder's overall evaluation of a \\
\hline
\end{tabular}




\begin{tabular}{|c|c|}
\hline & company over time" \\
\hline Herbig and Milewicz (1995) & $\begin{array}{l}\text { "Reputation is the estimation of the consistency over time of an } \\
\text { attribute of an entity" }\end{array}$ \\
\hline Highhouse et al. (2009) & $\begin{array}{l}\text { "Corporate reputation is a global, temporally stable, evaluative } \\
\text { judgment about a firm that is shared by multiple constituencies" }\end{array}$ \\
\hline Post and Griffin (1997) & $\begin{array}{l}\text { "Corporate reputation is a synthesis of the opinions, perceptions, } \\
\text { and attitudes of an organization's stakeholders" }\end{array}$ \\
\hline Wartick (1992) & $\begin{array}{l}\text { Corporate reputation is "the aggregation of a single stakeholder's } \\
\text { perceptions of how well organizational responses are meeting the } \\
\text { demands and expectations of many organizational stakeholders" }\end{array}$ \\
\hline Wilson (1985) & $\begin{array}{l}\text { "In common usage, reputation is a characteristic or attribute } \\
\text { ascribed to one person (firm, industry, etc.) by another [...] } \\
\text { Operationally this is usually represented as a prediction about } \\
\text { likely future behaviour" }\end{array}$ \\
\hline Wilson (1985) & $\begin{array}{l}\text { "A company's reputation reflects the history of its past actions }[. . .] \\
\text { and affects the buyer's expectations with respect to the quality of } \\
\text { its offerings" }\end{array}$ \\
\hline
\end{tabular}

In literature that concerns corporate reputation, reputation is perceived as an evaluation by the stakeholders, based on past performance of the company. "Corporate reputation is a perceptual representation of a company's past actions and future prospects that describe the firm's appeal to all of its key constituents." (Fmbrun C. 1996). In such a way, reputation is seen as a sum of individual perceptions among all stakeholder groups that are interested. At a later stage, reputation is seen as a "subjective, collective assessment of an organization's trustworthiness and reliability" Fombrun et all, (1997) among both internal and external stakeholders.

We can conclude that the definition of reputation refers to the presumption of fulfilling stakeholders' different expectations and needs by the company, and the ability and willingness the company to deliver for the stakeholders.

\section{The reputation as an intangible asset}

Intangible assets are in greater demand and their importance is greater than ever before. They are considered accountable for a company's success even greater than the control of tangible and physical assets. Traditionally, the intangible assets are associated with nonphysical assets as patents, client database, market knowledge, strategic alliances and others, employee profiles. For some companies, the brand is the most valuable asses that might correspond to approximately $70 \%$ of their total market value.

Reputation is also considered an intangible asset with growing value and importance for the organizations. According to Helm a good reputation allows the company to:

1. attract better applicants as a workforce

2. charge clients with premium prices

3. attract investors

4. attract capital on lower cost

5. reduce customers' uncertainties.

Reputation is seen by Huber (Huber, 2017). as "the most important intangible asset that it can own and is an important differentiation criterion in international markets", important, key intangible asset.

As an intangible asset, reputation is sending signals to the interested parties about the attractiveness of a company's initiatives, performance and status. Reputation reconciles the multiple 
external images of firms, and signal their overall attractiveness to employees, consumers, investors, and local communities. According to Fombrun (Fomrun, 2006), reputation is of great matter because it creates value via attracting better and more valuable resources to those companies that are better regarded. As an intangible asset, reputation creates value for the company mainly in the following areas:

1. Making the company an "employer of choice" by improving the company's ability to attract and recruits' applicants and retain the current employees

2. Making the company a "supplier of choice" by attracting the customers to the company's services and products and enhancing repeating purchases

3. Making the company a "partner of choice" and obtaining better and even favourable treatment by the local communities, medias, authorities

4. Making the company "investment of choice," enriching the company's ability to attract capital at a lower cost, compared to the competitors and rivals, and enhancing premium prices for the company's shares on the stock market.

According to Chajet, (Chajet, 1997) 'The more stockholders there are, the more people will be sensitive to the reputations of the companies in which they are investing. Nevertheless, the return of the investment stays the main factor for investing in a company, the reputation of the company is a important decision taking factor. The shareholders are getting more sensitive to the reputation of the company, they are investing in. According to Hanson, (Hanson et all, 2001) "shareholders may be interested in profit but they will also share the shame and declining profits associated with a deteriorating corporate reputation which is now increasingly the subject of media and public scrutiny".

Basically, we can identify 3 main groups of stakeholders that are particularly interested in the company reputation - clients, employees and stakeholders. Although, according to this perspective, the clients and employees can also be considered as stakeholders, at this case we are referring mainly to shareholders, local communities and authorities.

In addition to scientific researchers, the practitioners and companies also recognize reputation as an intangible asset. A survey conducted by the consultancy group Nielsen Holdings (2014) confirms, that a good reputation stimulates purchasing and the high satisfaction among clients. The survey was conducted among 30000 customers from 13 countries worldwide. $66 \%$ of the respondents are eager to pay even higher price for goods and services, if they are provided by a company with great reputation. The companies, subject of the survey, that are possessing sustainable reputation, have reported an increase of $4 \%$ of the sales. This is compared to $1 \%$ sales increase among the rest of the firms. Additionally, reputation influences and fastens the decisionmaking process. $60 \%$ of the respondents would deny a service or purchase, should they come across a few negative reviews of the company.

More frequently, customers are making decisions to buy from one company or another, based on corporate reputation that concerns employee treatment. The consumers are considering themselves as investor and are taking educated determination which company to support Luca M., Luca D.L (2016)12. The consumers are getting more and more interested not only what they are buying, but from whom.

Employee retention, attracting good candidates, reducing turnover, employee satisfaction are variables, usually included in the strategic, tactical and operational plans for human resources of an organization. However, they are also an element of online reputation. A survey conducted in 2014 by RC Magazine and Alexander Mann consulting group surveyed 1,014 individuals. According to the results, $93 \%$ of respondents indicate that they prefer to work for an organization with a good reputation. Experienced and qualified employees would also prefer a company with a good reputation. Young people / 18 years - 34 years / and those who do not have much experience, would rather not affect the reputation of the company when deciding whether to work for it /. Reputable 
organizations have lower hiring costs as well as lower turnover. $70 \%$ of employees would replace their current one with a company with a better reputation.

The reputation of an organization is one of the most important and intangible assets in terms of attracting new employees. When unique and unrepeatable, an organization's reputation is a key source of competitive advantage. CEOs often recognize reputation as one of their most important assets. Good reputation is seen as a factor in attracting better employees. According to Yang (Yang et all, 2013) the organization's attitude toward employees is now part of the customer's purchase decision. Executive directors should be vigilant about the internal organizational culture, which is quickly made available to the general public. Users are sensitive to all signals and information coming from and about the company.

\section{Methodology of the research}

The companies from Northeast planning region are also considering reputation of the organization as an intangible asset. The following survey and the findings within are showing that the understanding of this topic is not uncommon.

The object of the study are non-financial enterprises from the Northeast planning region, with staff from 10 to 249 people. 3812 firms are covering this criterion. The research is realized in several successive stages: formulation of a research problem and setting goals, determination of limited conditions for the research, research methodology, preparation of research tools, test and administration of the questionnaire, realization of the research, analysis and interpretation of the obtained data. The volume of representative sample equals to 350 companies. The number is calculated under $5 \%$ mistake $(\Delta=0.05)$. A survey method was chosen using a survey, which is completed online by the respondents. The survey was conducted in the period 01.02.201901.04.2019.

\section{Main findings of the survey}

The obtained data show that out of 320 surveyed representatives of organizations, $59.7 \%$ hold a leading position, and $40.3 \%$ hold an expert position. $49.06 \%$ of the respondents have work experience between 11 and 20 years, which is a dominant group. The respondents with up to 10 years of experience are $22.8 \%$. Those with work experience over 20 years - 28.1 percent.

$52 \%$ of the organizations or 169 has a staff of 10 to 90 people. This is also the dominant group according to these criteria. 27.5 percent have staff from 91 to 170 people, and the remaining $19.7 \%$ of organizations - staff between 171 - 249 employees. The organizations operating in the field of construction dominate with $28.1 \%$. The companies from the tourism sector are 24.7 per cent of the sample or 79. The companies from outsourcing and trading area are showing a practically equal distribution $-18.1 \%$ and $18.5 \%$, respectively. Consulting services and other activities are represented by $0.65 \%$ and $1.56 \%$ respectively.

55.6 percent of the surveyed 320 people categorically perceive with "yes" the reputation of the organization as an intangible asset. Another 27.5 say "rather yes." 6 percent of the persons show skepticism, while another 10.9 percent remain neutral on this issue. We can comment that the majority of $83.2 \%$ of respondents perceive the reputation of the organization as a tangible asset. / Figure 1/. The focus of the question "The organization I represent invests in reputation" is the answer "rather yes", indicated by 45.6 percent of the respondents. Definitely "yes" they indicated 37.5 percent. $9.1 \%$ demonstrate neutrality on the issue, while $7.8 \%$ of organizations do not invest in their reputation.

We can comment that while the organizations definitely recognize the reputation of the organization as a tangible asset, they do not definitely invest in it.

However, some of the companies, are investing in this asset, via the variables, that forms the reputation. /Figure 2/ An object of interest of the empirical research is also the question through which variables and to what extent the organizations invest in their reputation. $50 \%$ invest in their 
reputation by improving the quality of products and services provided. The next most preferred area is the improvement of working conditions. This is distinctive for $44.4 \%$ of the organizations, with another $36.6 \%$ investing in sooner

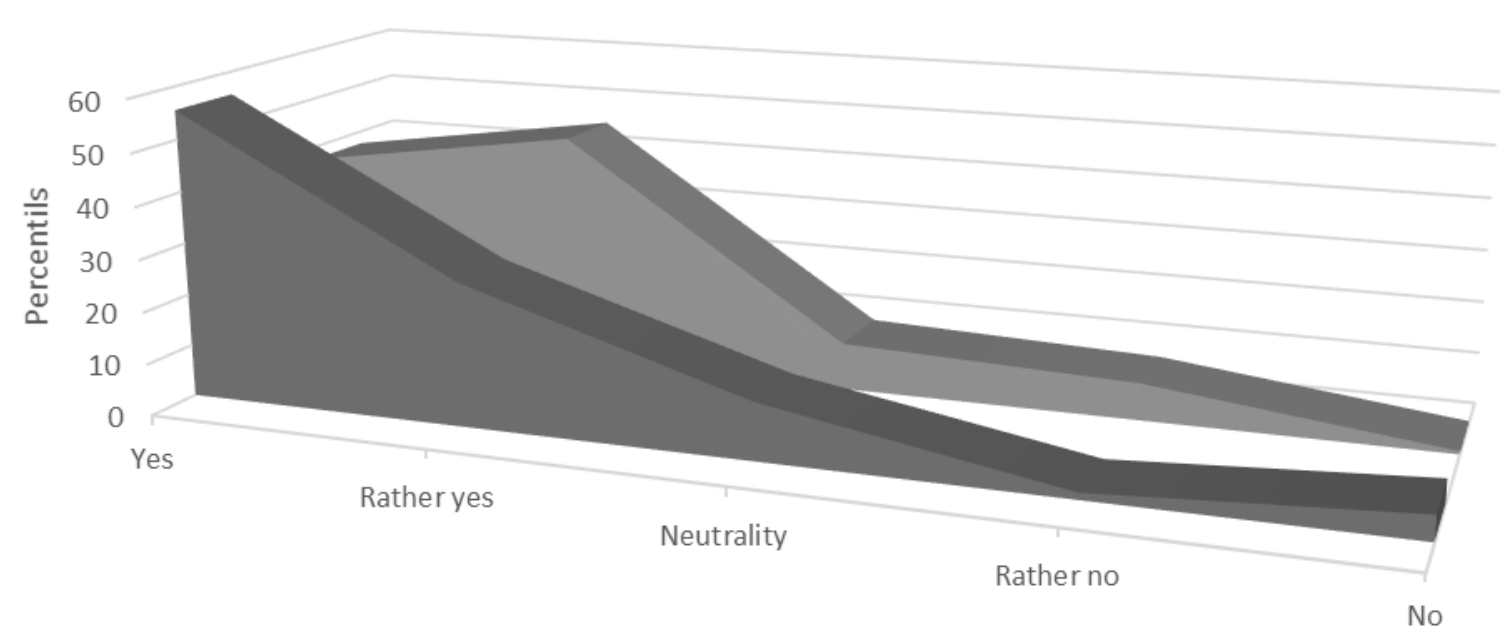

Заглавие на ос

- The reputation of the organization is an intangible asset

- The organization, I represent, invests on its own reputation

Figure.1 The reputation as intangible asset and subject of investment

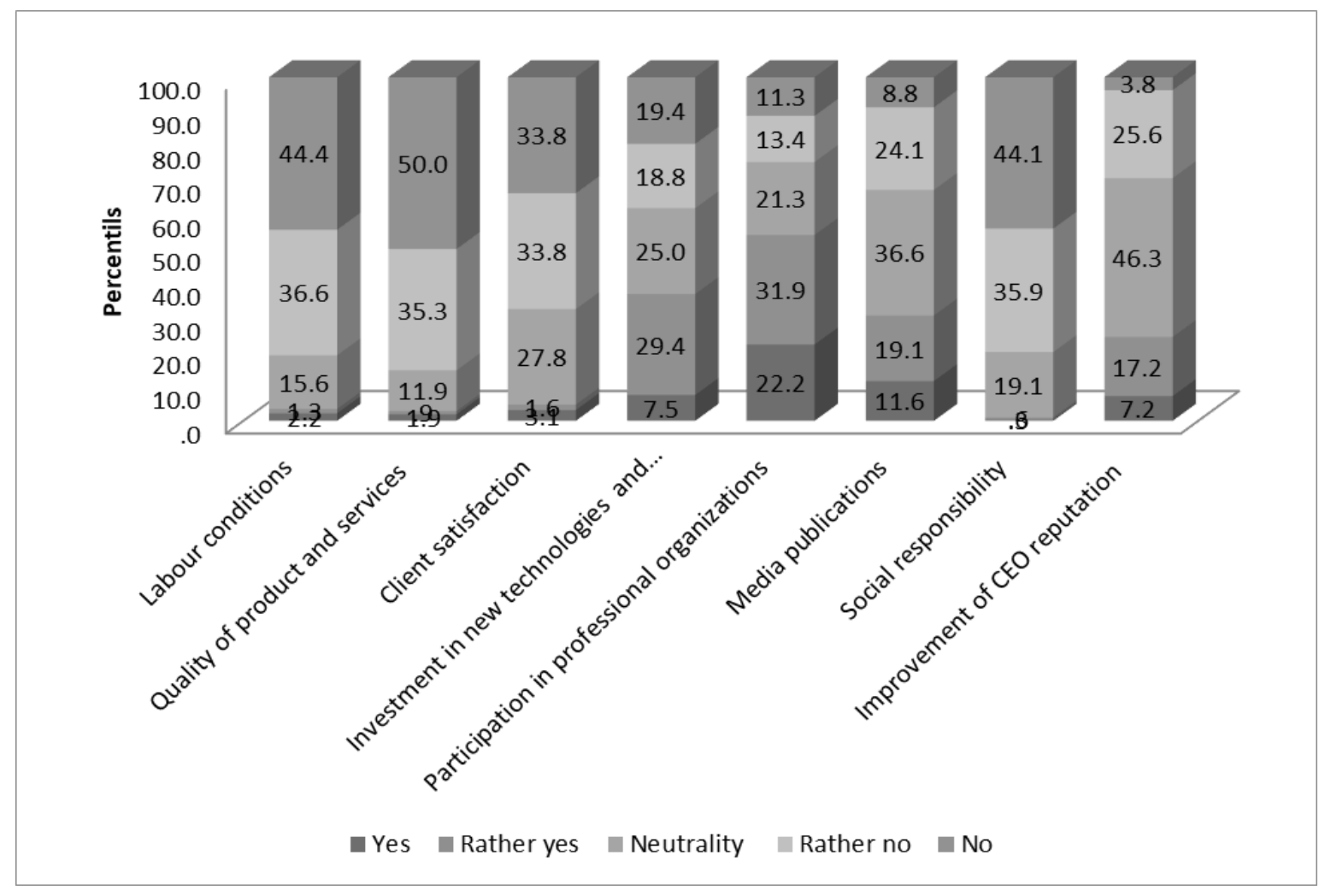

Figure.2 Areas of improving the reputation and investing into it 
There are practically the same indicators for social responsibility. $44.1 \%$ of the representatives of the organizations state, with "yes", that they invest in their reputation through investments in social responsibility / to quote $\mathrm{k}$. is social responsibility. 35.9 percent of the surveyed 320 representatives of companies said "rather yes" to this issue. Participation in nonprofessional organizations and publications in the media are the least preferred areas for investment - categorically "no" gave $22.2 \%$ and $11.6 \%$, respectively. In these two variables definitely invest 11.3 percent and 8.8 percent, respectively. In customer service, there are equal values between those who say "yes" and a hesitant "rather yes". Improving the individual reputation of the head of the company is also an object of investment, albeit to a symbolic degree. 3.9 percent said "yes" and 7.2 percent said "no". The dominant answer for this variable is "neither yes nor no" - 46.6 percent of 320 organizations.

We can comment that organizations invest in reputation mainly through investments in improving the quality of products and services, working conditions and customer service. Participation in professional organizations and media publications are practically not subject to investment.

Obviously, the reputation is not only perceived as an intangible asset, but the companies are investing in enchasing the reputation. Furthermore, the reputation is seen also as a factor for a strategic decision making. To the question "Do you perceive the reputation of the organization as a factor for strategic decision-making" $56 \%$ of the surveyed 320 people gave a positive answer. Another $39.06 \%$ chose "rather yes". $1.2 \%$ said "no". We could agree that in the vast majority of respondents, respondents perceive the reputation of the organization as a factor in making strategic decisions.

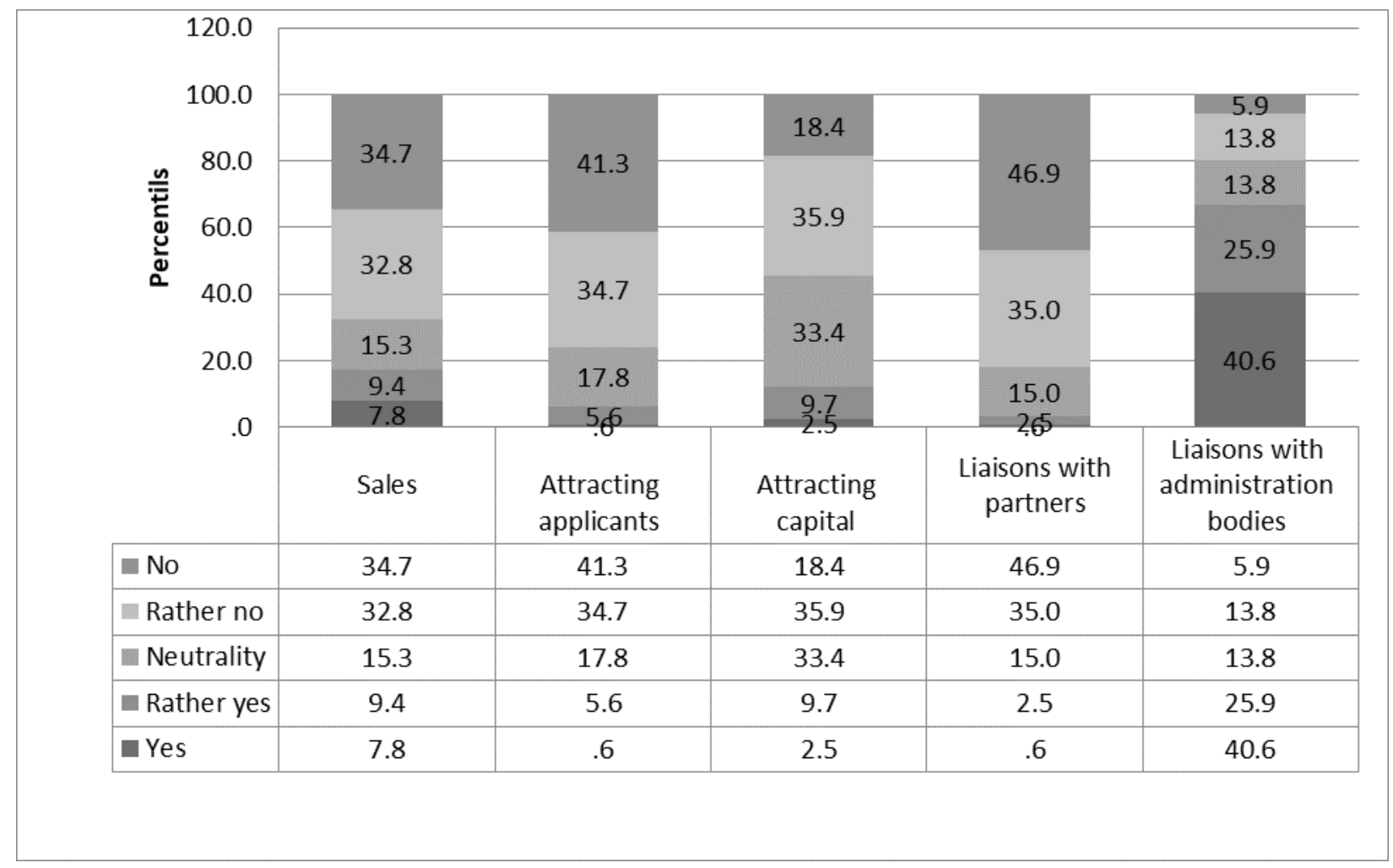

Figure.3 The reputation as a strategic decision-maker

As a factor in strategic decision-making, an organization's reputation influences decisions about factors that are related to its competitive advantage. $34.7 \%$ of respondents say "yes" to the question of whether reputation influences sales decisions. "Rather yes" indicated 32.8 percent. 15\% are reluctant to give an answer. These fluctuations are typical for $13 \%-15 \%$ of the respondents 
regarding the other variables. An exception is the attraction of capital in the survey, where $33.4 \%$ hesitate. Attracting job candidates received the full consent of 41.3 percent of respondents. The highest values of consent are in the relationship with partners - 46.9\%. 35\% of respondents indicated "rather yes" for this variable. The reputation of the organization has the weakest influence in making strategic decisions regarding relations with the state and municipal administration. 40.6 percent of the 320 respondents indicated a complete "no".

We can conclude that the reputation of the organization is a factor in making strategic decisions about variables related to the competitive performance of the organization. The emphasis is on relationships with partners and attracting job applicants, as well as sales. $61.8 \%$ of the persons in a leading position categorically perceive the reputation of the organization as a factor for making strategic decisions. $34.5 \%$ of them say "rather yes". This answer was indicated by $46.5 \%$ of the experts, and another $48.8 \%$ of them stated categorically yes. Negative answers are practically absent. We can comment that the reputation of the organization is recognized as a factor for strategic decision making.

\section{Conclusions}

Corporate reputation is gaining a growing interest among scholars and practitioners. As a multidisciplinary construct it is a subject of ongoing discussions and researches. Even the definitions are competing to describe the nature of reputation. The topic is evolving and the perception towards reputations is changing. Undoubtfully, reputation is seen as an intangible asset of great importance for the company - an asset able to influence different categories of stakeholders - from investors to employees, from local authorities to global customers. The role of reputation is becoming more important for the corporate word, as the companies are considering it, when they are about to make a decision. Also, the firms are investing in their reputation as they would do it for other assets. Those conclusions are mainly from international surveys.

However the presented research shows that Bulgarian companies from the Northeast planning region are also in the trend and they are realizing the value of reputation, recognizing it as an intangible asset, considerable upon decision making.

\section{References}

1. Alexander Mann Consultancy group (2014) "Why is Reputation Important in Business" [Online] Available from: https://alexandermannsolutions.com/alexander-mann-solutions-live/newsitem/it-pays-for-a-company-to-have-a-good-reputation

2. Chajet, C. (1997) 'Corporate reputation and the bottom line', Corporate Reputation Review magazine Vol 1, pages 19-23.

3. Feldman P., Agarwal J., Osyevskyy A. (2014) "Corporate reputation measurement: Alternative factor structures, nomological validity and organizational outcomes". Journal of Business ethics, Springer Science Business Media Dordrecht, page 8 - 9

4. Fombrun C. (1996). "Realizing Value from the Corporate Image”, Harvard Business School Press, Boston 1996, pages 10 - 22

5. Fombrun C. van Riel C (1997) "The reputational landscape". Corp Reputation Rev Vol 1 pages $5-13$

6. Fombrun J. (2006). "Corporate Reputations as Economic Assets" The Blackwell Handbook of Strategic Management. Blackwell Publishers Ltd. pages 313 - 320

7. Hanson, D. and Stuart, H. (2001) 'Failing the reputation management test: The case of BHP, the big Australian', Corporate Reputation Review, Vol 4, pages 128-143.

8. Helm C. (2007). "The Role of Corporate Reputation in Determining Investor Satisfaction and Loyalty" Corporate Reputation Review, Vol 10, pages 22-37

9. Helm C. (2011) “Corporate Reputation: An Introduction to a Complex Construct”, Reputation management, Springer, 2011 page 6 
10. Huber C. (2017) “The Corporate Reputation of Multinational Corporations”, Dissertation Trier University, Springer, pages $117-118$

11. Luca M., Luca D.L., Harvard Business School "Reviews, Reputation, and Revenue: The Case of Yelp.com" [Online] Available from http://www.hbs.edu/faculty/Pages/item.aspx?num=41233

12. Nielsen Holdings Consultancy group (2014) "Consumer-Goods' Brands that demonstrate commitment to sustainability outperform those that don't" [Online] Available from: https://www.nielsen.com/eu/en/press-releases/2015/consumer-goods-brands-that-demonstratecommitment-to-sustainability-outperform/

13. The Compact Oxford English Dictionary (2008) [Online] Available from: http://www.askoxford.com/ concise_oed/orexxputation

14. Webster M. (1976) Websters Collegiate Thesaurus, Dictionary, MA Springfield, page 315

15. Yang. T., Cable M. (2013) "Corporate Social Performance Organizational Reputation and Recruitment", The Oxford Handbook of Recruitment, Oxford university press, page. 299 